\title{
The Continuous Use of Asbestos in Ghana Despite Its Hazards (Case Study Area: Sekondi-Takoradi)
}

\author{
Peter Paa-Kofi Yalley ${ }^{1}$, Philip Kwaw ${ }^{2}$ and Chris Nat Ndede ${ }^{2}$ \\ 1. Design and Technology Department, University of Education, Kumasi 00233 32, Ghana \\ 2. Civil Engineering Department, Takoradi Polytechnic, Takoradi 00233 31, Ghana
}

Received: August 31, 2011 / Accepted: October 31, 2011 / Published: April 20, 2012.

\begin{abstract}
This paper reported on a research work conducted with the aims of investigating the regulatory position regarding the use of asbestos and also of assessing the evidence of the continuous use of asbestos cement products in the construction industries in Ghana, using Sekondi-Takoradi as a case study area. This paper adopted both quantitative and qualitative research approach to seek information from, landlords, and manufacturers of asbestos cement products, parliament and other Government Agencies. Data was obtained through questionnaire, interview and field work survey. In all, a total of 20 questionnaires were distributed. The research emerged that about 1200 housing units roofed with asbestos cement roofing sheet were constructed by the state owned construction company between 1976 and 2000 in the Sekondi-Takoradi Metropolis (about 12,000 nationwide), a period when the risk of asbestos was known in Ghana. The study in the newly developing areas in the Sekondi-Takoradi Metropolis indicated that, out of every 100 housing unit being built, at least 40 of these were roofed with asbestos cement corrugated roofing sheet. It was also emerged from this research that there were no laws prohibiting the use, manufacturing or importation of asbestos products in Ghana. And this exposes maintenance workers in the building construction industries to the risk of asbestos related diseases. The research recommended that those who have asbestos materials present in their premises should take action to manage the risk so that no one will unknowingly disturb it and also provide information about the material to those who are likely to disturb it.
\end{abstract}

Key words: Asbestos fibres, housing unit, Ghana, roofing sheet.

\section{Introduction}

This paper reports on a research conducted with the main aims of investigating into the regulatory position regarding the use and manufacturing of asbestos cements products in Ghana. Investigation into the continuous use of asbestos cement products in Ghana using Sekondi-Takoradi as case study area is also reported in this paper. In this study awareness is created on the health risk associated with the use of asbestos cement products with landlords and various decisions making bodies including parliament being the target groups.

\subsection{What Is Asbestos}

Asbestos is a naturally occurring fibrous material

Corresponding author: Peter Paa-Kofi Yalley, lecturer, Ph.D., main research fields: innovative materials, land, housing and environmental science. E-mail: yalleypp@yahoo.com. and has been used for about 150 years on a large scale. It is versatile, plentiful and ideal as a fire-proofing and insulation material. According to Sanderson [1] there are three main types of asbestos that have been used commercially.

These are Crocidolite (blue), Amosite (brown) and Chrysotile (white). Sanderson et al. [1, 2] agreed that all the three types are dangerous, but blue and brown asbestos are known to be more dangerous than the white.

\subsection{Physical Properties of Asbestos}

Asbestos is a strong, durable, non-combustible fibre. These physical properties make it ideal as a reinforcing agent in cement, vinyl and other building materials. Examples of these are vinyl floor tiles, bath panels, cold water cisterns, roof felts, corrugated or 
flat roof sheets, cladding sheets, soffit strips, gutters, and it's ideal for fire proofing and insulation.

Its ability to resist high temperatures made it so useful in the past. Asbestos is ideal for any process involving the conservation or preservation of heat. The fibre gives protection against fire, corrosion, cold, acids, alkalis, electricity, noise, energy loss, vibration, salt water, frost, dust and vermin [2].

Asbestos has been used extensively in the past and may be found in many forms in existing buildings including industrial wall and roof linings, internal partitions, duct and pipe covers, suspended ceilings, fire doors and soffits to porch and canopy linings. It also occurs in plant rooms and boiler houses and as asbestos coatings and insulating lagging on structures and pipe work [2].

\subsection{Disease Associated with Asbestos Fibres}

If disturbed, asbestos material may release asbestos fibres when inhaled into the lungs and accumulated, then several diseases may occur. According to Refs. [3, 4], there are four main diseases associated with inhalation of asbestos fibres. These are asbestosis (a scarring of the lung tissue caused by asbestos), two kinds of cancer (mesothelioma and asbestos related lung cancer), and diffuse pleural thickening (a non-malignant disease affecting the lung lining) [5].

Information on the perceived risk of cancer by asbestos is conflicting. While, evidence from Ref. [6] in their study on Quantitative Risks of Mesothelioma and lung cancer in Relation to Asbestos Exposure and Ref. [3] suggests that asbestos can also cause laryngeal cancer and may be implicated in causing pharyngeal, stomach and colorectal cancers, and that there is a link between asbestos and illness called Mesothelioma, i.e. lung cancer. Ref. [7] illustrated that there were the health effects that associated with asbestos as a result of inhalation of the asbestos fibers. On the other hand California Safe Drinking Water and Toxic Enforcement Act of 1986 reported that the use of asbestos cement products had not been demonstrated to be a health threat. In view of this, the California Waterworks Standards allowed for the use of asbestos cement pipe. Ref. [8] claimed there was no health risk related to the use of asbestos products and routinely approved engineering submittals calling for A.C.Pipe (asbestos cement pipe).

\subsection{Banning of Asbestos}

In 1989, EPA (USA) banned asbestos. In 1991, the US Courts (Fifth Circuit) vacated and reversed this EPA's ban claiming that EPA's analysis was unscientific and incomplete. In the same year, EPA issued final drinking water standards, wherein asbestos cement pipe was allowed, but conceded that the risk posed by asbestos substitutes such as PVC and ductile iron pipe, were far greater than those posed by A.C.Pipe. In the United Kingdom, in 1970, the asbestos industry maintained a voluntary ban on the import of raw blue asbestos into the UK. Then in 1980, they agreed to a similar ban on brown asbestos. The UK government finally imposed a legal ban on both blue and brown and any products containing them, in 1986. An attempt to introduce a phased ban on the use of asbestos in the European Community was narrowly defeated in March 1987. In 1992, Asbestos (Prohibitions) Regulations amended to include ban on rarer forms of Amphibole asbestos (Tremolite, Actinolite and Anthophylite) [9]. Evidence from the work of Ref. [10] on Health and Safety in Construction made it clear that asbestos related diseases are responsible for around 4,000 deaths in the UK each year. This paper investigates into the efforts of the Government of Ghana on the regulation concerning the use and manufacturing of asbestos cements products in Ghana and also to find out whether Ghanaian public is aware of the hazards associated with asbestos products. This calls for the need to investigate into the regulatory position of Ghana Government and also to ascertain if there is a continuous use of asbestos cement products in Ghana using Sekondi-Takoradi as a case study area. 


\section{Research Methods}

Combination of quantitative and qualitative research methodology was used in this research. Data obtained for this research was through field work and questionnaire combined with interviews.

\subsection{Field Work}

The field work was used in this research to assess the evidence on the use of asbestos cement products in the construction of dwelling houses in Ghana with Sekondi-Takoradi as a case study area. Five selected newly developed areas in Sekondi-Takoradi Metropolis were used for this study namely; Race course ridge, Anaji Namibia, Anaji Estate, Kojokrom new site and Apollo. The purpose for selecting these communities was that these communities started developing when the dangers of using asbestos-cement product were known to the building regulatory bodies (like Building inspectors, Town and country planning, and Ghana standard board), Engineers, Architects and contractors, yet there was continuous use of asbestos roofing sheet in these areas.

The fieldwork also served as an overview of the asbestos problem, by assessing the opinions of house owners in the five selected areas with the focus of creating awareness of the dangers in the use of asbestos. The field work also aimed at advising those who have asbestos materials present in their premises on how to manage the risk so that no one will unknowingly disturb it and also provide information about the material to those who are likely to disturb it. During the field work, three simple questions were asked to assess the knowledge of owners and dwellers of houses with asbestos cement roofing sheets as roof cover.

\subsection{Questionnaire}

A combination of interview and questionnaire approach was used in collecting data for this research beside the field work. More often than not, the response to interview approach of administering questionnaire in data collection is much higher than the postal questionnaire approach [11]. Chief Executives and Directors from the under listed organizations were interviewed:

- Cemonit Ghana Ltd.-(asbestos manufacturing company);

- Ghana Medical Services;

- Ministry of Health;

- Korle BU Teaching Hospital;

- Trade Union Congress (TUC);

- Building and Road Research Institute (B.R.R.I);

- Ministry of Resources, Works and Housing;

- Ghana Standards Board;

- Public Works Department;

- Food and Drug Board;

- Ministry of Justice-Judiciary Service;

- Ministry of Justice-Attorney General;

- The Parliament House;

- Komfo Anokye Teaching Hospital;

- STMA (Local Authority in Sekondi Takoradi).

In all, 20 persons from these organizations responded to the questionnaire. They include four members of parliament, two from Ghana Standard Board, three Medical practitioners, two from Cemint Ghana Ltd, and one each from the rest of the organizations. The personnel from the above named organizations were given statements that were related to the practice and control of asbestos in the construction industry, which are elaborated in Section 3.2. The respondents were given the choice to express their degree of agreement or disagreement on a particular statement. The set of response quantification categories are as follows: strongly agree (5 points), agree (4 points), neither/nor (3 points), disagree (2 points) and strongly disagree (1 points).

There was separate questionnaire for personnel in the manufacturing company. These questions were designed to solicit information from "Cemonit Ghana Ltd”, the only asbestos cements products manufacturing industry in Ghana. 


\section{Analysis of Results}

This section describes in details the outcome of the research in the field work, questionnaire and interview that were conducted.

\subsection{Results from Field Work}

Table 1 contains the data obtained from the field work conducted in the five selected communities namely: Anaji Namibia, Anaji Estate, Race Course Ridge, Apollo and Kojokrom new site.

From the data in Table 1, it was evident that the percentage of houses with asbestos cement roofing sheets in the five selected communities was on the average about 450. Anaji Namibia and Anaji Estate has $62 \%$ and $76 \%$ respectively, of houses roofed with asbestos cement roofing sheet. These two communities were developed by State cooperation now State Housing Company. Anaji Estate and Anaji Namibia were developed in the late 1970s and early 1980s, respectively, a period when the health hazards on the use of asbestos products were known. Apollo, Kojokrom New site and Race course Ridge have percentages of houses roofed with asbestos to be $23 \%$, $42 \%$ and $22 \%$, respectively. These communities were developed in the 1980s and 1990s by private individuals. If the government of Ghana had acted earlier, on legislature regulating the use of asbestos products and also creating awareness on the hazard associated with asbestos products, these individuals might not have roofed their houses with asbestos cement roofing sheets. Landlords were interviewed during the field survey. In all, 10 landlords were interviewed in each of the five selected areas. The questions asked are summarized below:

- Why did you use asbestos cements roofing sheet on your building?

- Are you aware that asbestos has some health risk hazard?

- If you were to build a house again would you use asbestos cements roofing sheet?

Respondents were asked why they used asbestos cements roofing sheet on their roofs. Twenty land lords from Anaji Namibia and Anaji Estate said they did not take part in the decision on the use of asbestos, since they bought their house from the Government. Twenty-four landlords from Apollo, Kojokrom New site and Race course Ridge answered that asbestos roofing sheets were relatively cheaper and could withstand the effect of the sea breeze. While, six landlords said they were advised by the construction workers working on their buildings. Respondents were asked whether they were aware that asbestos had some health hazard? Half of the respondents were not aware while a quarter of them were aware. The last quarter of the respondents had heard of the health risk but did not believe it was true.

If you were to build a new house, would you use asbestos cements roofing sheet? To this question three-quarters of the respondents answered no, while, a quarter appeared indifferent. The response to the last question indicated that at least the interaction with some of the Landlords had created certain level of awareness on the health risk related to the use of asbestos cements products.

\subsection{Details of the Responses to the Questionnaire}

Two separate questionnaires were given to two set of groups namely: chief Executives of selected Government Agencies and directors of the asbestos manufacturing company.

Table 1 Houses in the five selected communities.

\begin{tabular}{lllll}
\hline Community & $\begin{array}{l}\text { Starting date of } \\
\text { the community }\end{array}$ & No. of housing units & $\begin{array}{l}\text { No. of houses roofed } \\
\text { with asbestos sheet }\end{array}$ & $\begin{array}{l}\text { Percentage of houses roofed } \\
\text { with asbestos sheet }\end{array}$ \\
\hline Apollo & 1984 & 1,000 & 230 & 23 \\
Kojokrom new site & 1995 & 1,000 & 420 & 42 \\
Namibia & 1980 & 1,000 & 620 & 62 \\
Race course ridge & 1996 & 1,000 & 210 & 22 \\
Anaji-Estate & 1972 & 1,000 & 760 & 76 \\
\hline
\end{tabular}


3.2.1 Responses from Chief Executives from Government Agencies

Table 2 is the ranking data of the ordinary scale measure, the numbers assigned to the agreement or disagreement scale $(5,4,3,2,1)$ do not indicate that the interval between the scales are equal nor do they indicate absolute quantities. They are numerical labels. Each opinion question in the table requires the respondent to indicate strongly agree (coded 5), agree (coded 4), neutral (coded 3), disagree (coded 2) or strongly disagree (coded 1). A total of 20 responses were received from 20 Government organizations and manufacturers.

They included four members of parliament, two Directors of Ghana Standard Board, three Medical practitioners, two Directors of Cemint Gh Ltd, and one representative each from the rest of the organizations. The responses to the questionnaire are summarized in Table 2.

The following statements were the contents of the questionnaire:

(1) Statement 1-“Asbestos is the genetic term for a wide range of minerals that crystallize to form fibres. Most common is the white, blue and brown asbestos.”

With reference to Table 2 all the respondents agreed to the statement, meaning, the term asbestos is very familiar. It should be said that most of the respondents were professionals with knowledge in construction or medicine.

(2) Statement 2-“Although asbestos is a hazardous material it can only poses a risk to health if the

Table 2 Response of questionnaire.

\begin{tabular}{|c|c|c|c|c|c|}
\hline Questions & SA & A & $\mathrm{N}$ & $\mathrm{D}$ & SD \\
\hline 1 & 8 & 11 & 1 & 0 & 0 \\
\hline 2 & 9 & 10 & 1 & 0 & 0 \\
\hline 3 & 8 & 11 & 1 & 0 & 0 \\
\hline 4 & 2 & 16 & 2 & 0 & 0 \\
\hline 5 & 7 & 10 & 3 & 0 & 0 \\
\hline 6 & 14 & 4 & 1 & 0 & 1 \\
\hline 7 & 15 & 5 & 0 & 0 & 0 \\
\hline
\end{tabular}

asbestos fibres become airborne and are then inhaled”.

Considering the responses to this statement, many of them understood the problem caused by asbestos material. The literature of the statement explained further to respondents the hazardous nature of this material and how one could be exposed. From Table 2, at least 19 out of 20 responses agreed to the statement. One respondent confirmed that the question was not quite clear, hence, remained neutral to the statement.

(3) Statement 3-“For a long time the dangers on the use of asbestos were not widely understood. Asbestos related disease generally takes many years, often several decades to develop exposure. Thus, the scale of the health risks was only becoming known after asbestos had already been widely used and many people had already been exposed”.

With reference to Table 2, the respondents who neither agreed nor disagreed said that she was not quite familiar with the statement. All the rest agreed with eight expressing their strong agreement to the statement.

(4) Statement 4-“As asbestos fibres accumulate in the lungs, several diseases may occur:

- Mesothelioma is a cancer of the pleural and peritoneal lining;

- Lung cancer is a malignant tumor of the bronchi;

- Asbestosis is a scarring of the lung tissue;

- Diffuse pleural thickening is a non-malignant disease;

- Small areas of scarring are called pleural plaques”.

This statement explains the diseases which are caused as a result of asbestos exposure. All the respondents agreed with the statement except one respondent who was not sure about the statement. This respondent remains neutral to the statement.

(5) Statement 5-“The highest mesothelioma risk in the UK and the EU today is seen in occupations predominantly associated with construction and building maintenance highlighting a shift away from the traditional asbestos industries of the past”. 
The statement gives analysis on the highest risk of exposure to asbestos pertaining to various occupations. The occupations are mostly Carpenters, Plumbers, Electricians, Labourers and other construction trades, construction operatives, and managers in construction, the highest mesothelioma risk of asbestos being construction workers. This statement brought into view, the need to manage asbestos in the work place to ensure safety among workers.

With reference to Table 2, it could be shown that three respondents neither agree nor disagree with the statement due to lack of knowledge about the information provided by the questionnaire. At this point of the interview, respondents expressed their excitement and were alarmed on this information if it turns out to be true.

(6) Statement 6-“There is a ban on the use of asbestos products such as asbestos cement sheets, and any product containing asbestos materials in the UK and the EU countries. Do you think that Ghana should follow this example"?

The question sought to know if measures being put in place in the UK and the EU countries to reduce risks from asbestos would be equally appropriate to be applied in the construction industry in Ghana. The results recorded two respondents, of which one marked neutral whereas, the other disagreed on the ban of asbestos cement materials in Ghana.

(7) Statement 7-“Your organization can contribute in the management of the Asbestos problem by way of raising awareness, initiating legislation on the control and if possible ban the use of Asbestos products in Ghana”.

The idea underlying the statement was to persuade the legislature and chief executives of Government Department to use their position to influence the making and implementing of an Act of law regulating or possibly banning the use of asbestos products in Ghana as in the United Kingdom and the European Union countries.

The general consensus of the respondents was in total agreement with this statement. The respondents of the questionnaire comprised some parliamentarians and chief executives of selected Government Departments. From their responses to the statements in the questionnaire it could sum up that if people, particularly workers involved in construction and maintenance, have the potential to be exposed to asbestos, then Ghana should consider enacting a law banning the manufacturing, importation and the use of asbestos products .

From the discussions, the authors with the respondents showed that some professionals in the construction industry did not have an in-depth knowledge about the hidden killer-Asbestos. However, it is feared that, until enough campaign or awareness is created on the health risk of asbestos products, many people could be exposed to the health hazard.

3.2.2 Questionnaire for Manufacturing Companies

The only manufacturing of asbestos products in Ghana (Cemonit Ghana Limited) was asked to answer the following questions in the questionnaire:

(1) What is the core business of your company? The question seeks to obtain an idea about the operations and activities of the company;

(2) How long has your company been in production in Ghana? The question requires history of the company, the extent of existences of asbestos products in the country;

(3) State whether your company is the only firm producing asbestos fibres reinforced product(s). This question seeks to determine the number of asbestos products manufacturing companies in the country;

(4) What are some of the factors contributing to the widely use of asbestos products in Ghana? The question seeks to find out why people use asbestos products and why are the products so popular in Ghana;

(5) Give brief outline description of the manufacturing of asbestos products and/or provide sample of materials for the production of one asbestos product. This question was asked in order to establish 
the fact that there was presence of asbestos material in their products, and if possible to identify types, and constituents of asbestos material being used in the manufacturing of asbestos products in Ghana;

(6) Are you aware of any health hazard associated with the use of asbestos products-This question sought to establish whether people were aware of the health risks associated with asbestos and also as a reminder to producer to act on the issue in question;

(7) Following a ban on the use of asbestos in the European Union and the UK due to the known occupational health hazard caused by asbestos fibres. Manufacturers were asked if they have any alternative roofing materials to replace asbestos. It should the banning of asbestos to be enforced in Ghana. This last question was to emotionally prepare management to think of alternative material to asbestos, should there be any ban.

\subsubsection{Summary of the Manufacture's Responses}

The respondent stated that their activities were the manufacturing of asbestos cement based products including roofing sheets and pipes and that it was the only manufacturing company of asbestos products in the country and had been in operation for 20 years.

It was also revealed that the firm could not meet the demand of their customers and this had compelled the Government to allow importers to import asbestos cement products into the county. This then implies that the asbestos products are widely used in Ghana despite its health hazards.

The manufacturer was asked to state some of the factors influencing the use of asbestos cement products in Ghana. The answers to this question were that asbestos cement products were cheaper and durable. The manufacturer also added that the hazards associated with asbestos products were not known to the general public. It was also certain that the manufacturer (the respondent) was aware of the health problems associated with asbestos cements products so had put precautionary measures in place to control the risk to the workers and the surrounding community being infected by any asbestos related disease. According to the respondent their products are manufactured in the wet state, and this eliminates dusty particles into the atmosphere. The respondent also emphasized that there was regular medical examination for all workers.

Finally, on the question-whether asbestos products should be banned in Ghana? The respondent could not give a precised answer, however, responded that they did not expect any ban on their products. The reason for their opinion is that since their company adopts a wet process system in the preparation of its products, there was likelihood that the hazard was largely eliminated, and this could warrant their continued existence in business.

The conflicting views from literature make it inconclusive to demonstrate a health effect from asbestos products. However, the authors took a bias position that asbestos products pose health hazard. This is evident from the type of questions or statements in the questionnaire.

\subsection{Regulatory Position Regarding the Use of Asbestos in Ghana}

The Ghana Standards Board is the regulatory body in Ghana. It gives certification for Cement Based Construction Products in accordance with the certification Mark, Rules 1970 LI 662. The certificate is an attestation of a product's compliance with specified requirements of a relevant standard. In an interview with officials of GSB, it was clear that the Ghana Standards Board continues to give approval to manufacturers of asbestos cement products, and this had made asbestos manufacturers and importers to continue to promote and develop asbestos cement products in the country.

When the authors visited the manufacturing industry, Cemonit Ghana Ltd, it was learnt that asbestos cement roofing sheet produce in Ghana had asbestos to cement ratio of 1:10. Surprisingly, this asbestos/cement ratio was not known to The Ghana 
Standards Board. However, The Ghana Standards Board was certain that the asbestos/cement ratio of asbestos of asbestos products produced in Ghana was insignificant. This according to the official makes the products virtually cement based and not asbestos based. The Ghana Standards Board classifies asbestos cement roofing sheets produces in Ghana as 'Cement based product' and therefore they are not dangerous.

It was learnt from the discussion with The Ghana Standards Board that there were no stringent measures on safe working policy at construction work places. This is a threat to the health of construction workers. The Ghana Standards Board has no legislative instrument or bylaws prohibiting the manufacturing, importation and the use of asbestos cement products in Ghana.

\section{Conclusions}

A research was conducted with the main aim of investigating the regulatory position regarding manufacturing, importation and the use of asbestos and also of assessing the evidence of the continuous use of asbestos cement products in the construction industries in Ghana, using Sekondi-Takoradi as a case study area. This research was conducted to ascertain the continuous use of asbestos roofing sheet irrespective of the associated health hazard; hence field work survey was conducted. The research also tried to find out whether regulating bodies, other government agencies, landlords and manufacturers of asbestos products were aware of the risk related to the use and manufacturing of asbestos cement roofing sheet. This led to questionnaire and interview of some personnel of the aforementioned enterprises.

In the fieldworks survey in the five selected communities in Sekondi-Takoradi, it shown that out of every 100 housing unit at least 40 of these housing units were roofed with asbestos cement corrugated roofing sheet. The research unveiled that more than $50 \%$ of landlords interviewed had at least heard of the health risk associated with asbestos product, but they did not consider its harmful since the asbestos material has not disturbed, and hence no release of asbestos fibres when inhaled into the lungs which could cause cancer. The outcome of this research also indicated that there were no regulations prohibiting the use of asbestos products in Ghana, rather the regulating agency (The Ghana Standards Board) continued to give permit to manufacturers of asbestos cement products and this had led to the asbestos producing industry in the country to continue to promote and develop its products and the importation of raw asbestos into the country. The Ghana Standards Board classified asbestos cement product produced in the country as cement based hence minimum health risk.

In contrast to the opinion expressed by the personnel of Government Departments the manufacturing industry was not in favour of the promulgation of asbestos regulation that would prohibit the promotion and development of asbestos cement products.

\section{Recommendations}

The research recommends that those who living in building roofed with asbestos cement roofing sheet or with asbestos materials presenting in their premises, should firstly, check the condition of the asbestos products, and secondly assess the risk of any asbestos containing materials. Thirdly, take action to manage the risk so that no one will unknowingly disturb it and finally, provide information about the material to those who are likely to disturb it.

\section{Way Forward}

This research found that there was a continuous use of asbestos roofing sheet in Sekondi-Takoradi irrespective of the associated health hazard and also there was no regulation regarding the manufacturing, promotion, importation and the use of asbestos cement products. The way forward would be to conduct a comprehensive interview with parliamentarian and to let them see the need to make a law regulating the use, 
promotion and the importation of asbestos cement products, if possible ban the use of asbestos cement products in Ghana.

\section{References}

[1] W.J.H. Sanderson, Asbestos for Surveyors, Bell \& Bain Press, Glasgow, 2007, pp. 1-4.

[2] J. Ridley, J. Channng, Safety at Work, 50th ed., Butterworth Heinemann press, London, 2001.

[3] Health and Safety Environment Report, HSE Press, London, 2002.

[4] National Comprehensive Cancer Network, Clinical Practice Guidelines on Oncology, Milignant Pleural Mesothrlimona, London, 2010.

[5] R.L. Cowie, J. Murray, M.R. Backlake, J.M. Samet, Occupational Pulmonary Disorders, 23rd ed., Sauunder
Elsevier, Philadalphia, 2007, Chap. 93.

[6] J.T. Hodgson, A. Darnton, The Quantitative Risks of Mesothelioma and Lungcancer in Relation to Asbestos Exposure: Status Report, Annual Report on Occupation and Hygiene, 2000.

[7] California Department of Health Services Report, Publication Manual for California Department of Health Services, California, USA, 1988.

[8] Texas Department of Health Services Report, Health Risk Related to the Use of Asbestos, Texas, USA, 1988.

[9] The Control of Asbestos at Work Regulations, Work Amendment Report, London, 1992.

[10] Ferret and Hughes, Health and Safety in Construction, Butter Worth Heinemann Press, London, 2008.

[11] S.G. Naoum, Dissertation Research \& Writting for Construction Students, Butterworth Heinemann Press, London, 2008. 